\title{
Cancellation Standard of Agreements Based on the Doctrine of Undue Influence in Court Verdicts
}

\author{
A. Budhiawan ${ }^{1}$, T. Kamello ${ }^{2}$, N. N. Sirait ${ }^{3}$, H. Purba ${ }^{4}$ \\ ${ }^{1,2,3,4}$ Faculty of Law, Universitas Sumatera Utara, Medan, Indonesia \\ adlinbuser@gmail.com
}

\begin{abstract}
The doctrine of undue influnce has now become one of the new grounds of will defect to cancel the agreement or contract in the court's practices. Undue influence as a condition of will defect is not set out in the Civil Code. This study discusses the cancellation standard of the agreement due to a defect of will be based on the doctrine of undue influence in the court judgments. The research method is a normative juridical through several approaches: doctrinal approach and theoretical approach that are associated with secondary data in the form of statutory provisions, and court verdicts relating to the legal problems. The results of the study found that the court verdicts to cancel the agreement based on the doctrine of undue influnce is occurs due to two main factors: the economic excellence factor and the psychiatric excellence factor. Several elements used to see the event are (1) the existence of a special circumstance, (2) a real thing, (3) abuse of circumstance, and (4) causal relationship. It can be concluded that undue influence doctrine is contrary to the principle of justice, the principle of freedom of contract, the principle of consensus, the principle of good faith, as well as the principles of decency and habit. It's recommended to form a legal norm in the Civil Code. The doctrine of undue influence should also be specified to limited circumstances of pre-contract, after execution of the contract, or because of a real loss for either the involved parties.
\end{abstract}

Keywords

cancellation standard, agreements, undue influence; verdicts

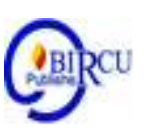

\section{Introduction}

Undue influence is one of grounds of will defects leading to cancel agreement in court practices. Standard implementation of the cancellation of the agreement / contract is based on the doctrine of undue influence are varied in the verdicts. There is no specific standard in the law or in the Civil Code as a reference but it depends on the case conditions, facts, and jurisprudence.

The Civil Code only recognizes the will defect that consists of coercion (dwang), oversight (dwaling) and deception (bedrog). A person who gives his/her agreement in any contract containing these three elements are then able to apply for cancellation of the agreement before the judge. Furthermore, in the development of law of obligations there is a current situation which does not contain those three elements, but, if the agreement is still being implemented, it is deemed not to fulfill the sense of justice.

Undue influence is a contract can be canceled because the will is not achieved due to a special position of one particular party such as their more dominant positions, confidential relationships or fiduciary relationships with other parties involved in the contract. In this case, the party that has the special position uses persuasive methods to take unfair advantage from other parties. Undue influence in an agreement on the basis of a one-sided can have 
economic and psychological advantages. Undue influence is a condition when a person in an agreement is influenced by something that prevents him from making judgments that are free from other parties. Therefore, he cannot take an independent decision.

Many agreements are indicated to have undue influence both in standard agreements / contracts and non-standard agreements / contracts. The most common undue influence is found in standard contracts (standard voorwaarden).

Communities that have legal relations with institutions are often faced with standard contracts that have been prepared by an institution. The original purpose was to facilitate legal relations. It turns out that a standardized agreement becomes a necessity to rise legal relations between the parties through misusing the situation by those who have economic and psychological advantages.

At first glance, undue influence makes a loss for one party and provides an opportunity for the other party. From this second element, arises the nature of actions which is the misuse of economic superiority and psychological excellence.

Undue influence is not regulated in the Civil Code but it is a doctrine that teaches the reason for cancelling the agreement. In legal practices, this doctrine has been widely applied by judges in Indonesian courts as a particular ground to cancel the agreement because it contains a defect of the will. Cancellation of the agreement based on the doctrine of undue influence in the court's verdicts, therefore, is an important issue to be discussed in this research.

\section{Research Methods}

The research is a kind of normative juridical research by utilizing several key approaches: doctrinal, theoretical, and statutory approaches. The secondary data were collected through library and documents studies. 4 jurists' verdicts from various levels of courts, such as high courts, supreme courts, etc. Were analysed in this research. The analysis was conducted in several steps. First, the whole verdicts were read. Second, one particular section of the verdicts, the consideration section, was deeply analysed in terms of the legal bases, legal principles applied by the jurists prior to the judgements. Third, the researcher analyzed the facts and legal events that were argued by the judges as the basis for the verdict in granting cancellation of the agreement based on the undue influence doctrine. Fourth, Then the researchers searched for the similarity of the criteria found based on the undue influence doctrine in each of these verdicts. Finally, at this point the researcher can formulate a particular standard of agreement cancellation based on the undue influence doctrine.

\section{Discussion}

\subsection{Undue Influence}

Misuse of circumstances (misbruik van omstandigheden) or is widely termed as undue influence is a factor that limit or interfere the formation of free will that is required by two parties involved in an agreement or contract. Undue influence occurs when one party knows or should understand the other party that due to particular situations such as emergency, dependency, inability to think further, and abnormality or inexperienced soul, they are moved to do a legal action even though they know or should understand that they actually have to prevent the agreement.

According to Van Dunne, undue influence involves conditions that contribute to the occurrence of a contract. Enjoying the circumstance of other party does not cause the 
contents of the contract or its intentions to be disallowed but it causes the will to be not free. Thus, undue influence occurs if one party is moved due to the special circumstances (bijzondere omstandigheden) to take legal action and its counterpart abuses it.

Undue influence makes use of economic or psychological advantages, such as special circumstances, the real thing, and causal relationships. Economic and psychological excellences are defective conditions that fulfill subjective conditions. The nature of the act of undue influence contains the abuse of economic excellence, and that of mental superiority. One party has abused the situation of the other party if the party has this advantage. One of the parties is indicated to have misused economic excellence and psychiatric superiority, and could harm the other party.

Undue influence over economic superiority is when one party utilizes economic advantage over the other party. This causes the other party is forced to accept the agreement. Misuse of the state of psychiatric superiority happens one party abuses the mental state of the other party, such as mental disorders, old age, inexperience, rashness, lack of knowledge, and poor body condition.

Undue influence is not solely related to the contents of the agreement but also relates to what has happened at the time of the making of the agreement since it is not free to determine the will. These concerns in the circumstances that play a role when the contract is made. One party enjoys the state of the other party and free will is abused to be non-free.

Undue influence in court practices is a new ground to cancel any agreement because it is deemed to contain defective will. This is a novelty in the field of treaty law in Indonesia and has been accepted as one of the grounds for cancelling the agreement because it contains defects in the will. Nevertheless, it is not yet regulated in the Civil Code.

\subsection{Terms of Will Defect in Civil Code}

The defect of the will is the defect in making an agreement in a contract / agreement becomes imperfect. When a contract contains a defect of the will, there appears to be an agreement but the agreement was made not on the basis of free will of the involved parties.

Will defects are subjective conditions for cancellation of the contract as specified in Article 1320 and Article 1321 of the Civil Code due to error (dwaling), threats (bedreiging), and fraud (bedrog). The Civil Code does not yet regulate the abuse of circumstances as one of the defective conditions of the will to cancel the agreement.

Many of the decisions of previous judges in the Netherlands that canceled agreements were based on circumstances that were contrary to customs, decency, and propriety. Abuse of the situation in the new Dutch civil law has been made as a condition for defects of the will beside errors, threats, and frauds.

The legal requirements of a contract according to Article 1320 of the Civil Code must fulfill: (1) an agreement for those who are bound, (2) the ability to make an agreement, (3) a certain thing, and (4) a cause permitted by law. The first and second conditions are subjective conditions while the last two conditions are objective conditions.

An agreement can be cancelled if the subjective conditions are not met which are agreed and legal competent. Anyone who does not agree definitely has a will defect. This means that there is an unwanted clause of one party (weak party) in the agreement that must be cancelled. Therefore, the agreement must be requested for cancellation through the judge's verdict. An agreement is null and void if the objective conditions are not met. Objective conditions emphasize that certain objects must be clear, halal, and not contrary to those are prohibited by law. If these objective conditions are not fulfilled, then the agreement is not plausible since the beginning. This is due to the objects of the agreement is unclear or the objects violate the law. 


\subsection{Doctrine of Undue influence in Jurisprudence}

Undue influence is a doctrine in the cancellation of an agreement / contract that is not yet included as one of the conditions of the defect of the will specified in Article 1321 of the Civil Code but implicitly contained in the subjective formulation in Article 1320 of the Civil Code.

Doctrine is the opinion of prominent jurists who discuss various legal issues and problems and include the judges' considerations in court verdicts. In legal considerations, judges often quote and make the opinion of famous legal experts the reason for their decision. Doctrine as a source of law has a large and important influence in the rules of international law.

As a doctrine, undue influence has long been accepted and originated from the doctrine of equity in common law countries which allows judges to make verdicts based on propriety, equality, moral rights and natural law. The doctrine of equity for the court may intervene in an agreement that contains the misuse of an unbalanced position between the parties.

Despite as a doctrine, undue influence meets the legal requirements and grounds to say that an agreement / contract containing an element of abuse is a flawed will that can be requested for cancellation from the judge.

Jurisprudence was first applied to the undue influence by judges in Indonesia: verdict of Suprement Court (MA) No.1904 K/Sip/1982 dated January 28, 1984 regarding the cancellation of contracts that indicated the existence of judges' authority to interfere with the contents of the contracts, and MA verdicts No.3431 K/ Pdt / 1985 Date 4 March 1987 about interest on loans and collateral items which are contrary to propriety and justice.

The court's consideration in Supremet Court Decree No. 1904 K/Sip/1982 dated January 28, 1984 applies the doctrine of misuse of circumstances by simply paying attention to the element of abuse of circumstances on the basis of economic and psychological superiority. While in the Supreme Court Decree No.3431 K / Pdt / 1985 dated March 4, 1987 the judge clearly applied the element of material loss as well as the misuse of the state of economic and psychological superiority.

\subsection{Doctrine of Undue Influence in Court Verdicts}

The doctrine of undue influence can be found in the jury's verdicts, among others; MA Verdict No.2988 K / Pdt / 2012; MA Verdict No.2131 K / Pdt / 2011; High Court Verdict of DKI Jakarta No. 398 / PDT / 2016 / PT.DKI; and High Court Verdict of DKI Jakarta No. 143/PDT/2016/PT.DKI;

\section{MA Verdict No. 2988 K/Pdt/2012, dated August 26, 2014}

The lawsuit of Nurtjahja Nugraha Tirtanata as a plaintiff on the basis of the undue influence was granted by judges of the South Jakarta District Court and the Jakarta High Court by arguing that Deed Number 2 dated May 7, 1997 and Deed Number 2 dated April 1, 1996 were legally flawed and had no legal force.

The plaintiff's lawsuit said that the defendant (Bambang Nuryatno Rachmadi and PT. Bank Asta) had exploited the Plaintiff's condition in a depressed mental state. The Plaintiff was pressured when making two deeds of case object, Deed No. 2 dated May 7, 1997 and Deed No. 2 dated April 1, 1996. Thus, the Plaintiff had to pay Defendant's loss of Rp.67.613.453.955,00.

In the case of this verdict, the judge at the first court (District Court) considered that there had been an undue influence due to the presence of special circumstances when the legal event occurred. The specific circumstances refer to the circumstances where one of the parties who approved or gave an agreement was in a state of distress or being pressed so the 
party was forced to give their agreement. The legal considerations of District Court judges were further strengthened by the Decision of the Judge of the Court of Appeal which reinforced the decision of the District Court Judge.

The Supreme Court canceled the decision of the South Jakarta District Court and the Jakarta High Court because the contents of the two deeds did not match the actual facts. According to the Supreme Court, there is no Plaintiff's debt to the Defendant or a depressed situation and does not meet the element of abuse of circumstances to cancel the agreement with Deed Number 2 dated May 7, 1997 and Deed Number 2 dated April 1, 1996.

\section{MA Verdict No. 2131 K/Pdt/2011, dated April 30, 2012}

PT. North Sumatra BPD (Defendant) was declared to have misused the state of its economic status. SHM (Certificate of Ownership) No.27 Pasar Ujung Batu Village a / n. Syamsiyah Lubis (Plaintiff 2) who was transferred to SHM No.77 Pasar Ujung Batu Village a / n. PT. North Sumatra BPD does not have legal force with all its consequences. Deed of Sale and Purchase No.3 / SOSA / 1996 dated 29 February 1996 made by the Plaintiff (H.M. Yunan Nasution) and the Defendant is invalid and null and void.

The Padangdisimpuan District Court, Medan High Court, and the Supreme Court agreed that the Defendant's actions were included as a misuse of the situation over the dominance of his economic status. The Plaintiff argues that the sale of land for the object of the case contains a defect in the will, because the Plaintiff as the seller is not in a free will position in determining his attitude to sell the object's land, and the Plaintiff's position with the Defendant when the sale is unbalanced where the Plaintiff's position is in a state of being pinched debt to the Defendant.

The Supreme Court said that the Defendant was not allowed to have objects that were pledged by making fake transactions, which were detrimental to the land owner (debtor) because he would get an unreasonable price. Agreements made by parties that are not economically balanced do not have the freedom to determine attitudes so they must be declared legally flawed.

From this verdict, it can be concluded that the judge accepted the doctrine of undue influence to be applied as a reason for canceling the agreement due to the following elements: (1) the existence of a special situation that exists in one party and by the other party it is known, (2) a party who is aware of the special circumstances experienced by the other party makes efforts to obtain their own benefits and incur losses on their opponent.

3. High Court Verdict of DKI Jakarta No. 398 / PDT / 2016 / PT.DKI, dated August 30, 2016

The Plaintiff (Kusumah Periatna) submitted a request to cancel the agreement toward the Deed of Agreement No. 22 February 13, 2006 made before Shella Falianti, SH, Notary in Jakarta (Co-Defendant 3) and the compensation payment agreement letter dated 20 September 2010. The Plaintiff's reason was because of the undue influence by the Defendant when the two agreements were made.

The District Court Judge stated that the Defendant was proven to have undue influence in the occurrence of the deed of agreement No. 22 On February 13, 2006 and the compensation payment agreement dated September 20, 2010 stating the two main deeds and other possible deeds that are related and containing similar acts made by and between the Defendant and the Plaintiff and / or the Defendant 1 was declared null and void.

In this case the economic excellence factor is the cause of undue influence with the several elements; namely, the existence of (1) A special condition: the plaintiff's situation that is less experienced and careless, (2) A real thing: the Defendant intentionally seized the opportunity to gain unilateral profit and cause harm to the Plaintiff, (3) Undue Influence: the 
Defendant intentionally persuaded and seduced the Defendant to sign the Deed of Agreement No. 22 February 13, 2006 and the compensation payment agreement letter dated September 20, 2010, (4) Causal relationship: if the Plaintiff knew the actual situation, the Plaintiff would not agree the Deed of Agreement N0. 22 February 13, 2006 and the compensation payment agreement dated September 20, 2010.

\section{Verdict of the DKI Jakarta High Court No. 143 / PDT / 2016 / PT.DKI, dated}

The agreement made by the plaintiffs regarding the binding purchase agreement dated July 11, 2008, is an agreement that is not based on free will. Initially it began with the deed No. 2 dated October 3, 2006. The Plaintiffs borrowed money from Defendant 1 for Rp.2,000,000,000.00 (two billions), but until the deadline of the debt settlement the Plaintiffs could not repay all of the debts. Then the Plaintiff reluctantly must sign a binding purchase agreement for the object of the dispute which is the joint property of the plaintiffs and is the sole residence for the Plaintiffs.

Then with this binding purchase agreement, Defendant 1 made Deed of Sale and Purchase No. 109/2008 dated August 20, 2008, before Ny. Sastriany Josoprawiro, S.H., Notary / PPAT in South Jakarta (Defendant 3). In making the deed of sale, the Defendant 1 acted as a seller (the first party) on the basis of absolute power of Plaintiff 1 and simultaneously acted as a buyer (the second party) in the ways that were not good. Then, Defendant 1 made arrangements at the South Jakarta Land Office (Co-Defendant) so that the land was transferred to Defendant 1. And finally the Certificate of Building Use Rights (HGB) Number 621 / North Petukangan was later upgraded to Certificate of Ownership (SHM). Number 3770 Petukangan Utara, on behalf of Lisa Juliana Tanjung (Plaintiff 1);

In this case, the judges both at the first and second level courts granted the cancellation of the binding sale and purchase agreements on the grounds that there was an element of abuse in terms of economic superiority owned by Defendant 1. And when both of these agreements were made the plaintiffs were in an economically weak state and pressed due to economic difficulties.

Besides that, there are several cases of cancellation of agreements submitted to the court using the reason of undue influence which were rejected by the judges, including;

\section{MA Verdict No.669 K/Pdt/2017 date June 13, 2017}

Akam as a Plaintiff filed a lawsuit against breach of contract because Edy Djon as the Defendant did not pay installments of the Plaintiff's sale of agricultural produce amounting to Rp.640,000,000.00. The defendant is of the opinion that the plaintiff's actions forced the defendant to sign the Agreement Letter dated December 23, 2012 as a misuse of the situation when the defendant was in a weak economy.

The Plaintiff's claim was granted by the Kotabumi District Court, the Tanjung Karang High Court and the Supreme Court (MA) on grounds of default. The Defendant finally had to pay Rp.640,000,000.00 to the Plaintiff, because of default, not because of abuse of circumstances. The amount of money Rp.640,000,000.00 that must be paid by the defendant to the plaintiff is not a material loss due to abuse of circumstances, because the money first appeared from the agreement, not due to the agreement which resulted in the defendant's loss of Rp.640,000,000.00.

In this case, the reason of the undue influence submitted by the petitioner / former Defendant of the Convention or Appeals was rejected by the judges at the First Level, the High Level until the judge at the Supreme Court. 
2. MA verdict No. $1843 \mathrm{~K} / \mathrm{Pdt} / 2012$, dated January 22, 2013

PT. Teguh Api Binatama, the Plaintiff, submitted arguments that their economic condition was weak when they signed the Amendment Agreement No. 057/PRPK/PB/ MGD/XII/98 dated 1 December 1998 in connection to the national economic recession that they were forced to hand over collateral assets to the Defendant, PT. Bank Mayora, and signed the Deed of Amendment even though the interest is high at $45 \%$ per annum and at any time the defendant can increase the interest rate and a fine of $2 \%$ per month. The plaintiff could not do much and was threatened to lose collateral assets if he rejects the Amendment Agreement.

Due to the extremely high interest rates, the plaintiff had difficulty in settling its obligations to the Defendant, and continued in the Defendant's efforts to auction off the Plaintiff's assets which were used as collateral for debt. The Defendant's actions which took time to confiscate the execution and auction resulted in an increase in the amount of the Plaintiff's liability that was improperly inflated. The Supreme Court rejected the request for cassation from the Plaintiff with the consideration that the Amendment Agreement, namely Deed No.057 / PRPK / PB / MGD / XII / 98, did not write off the mortgage right on the object of the case because the Plaintiff still owed the Defendant. The Plaintiff borrowed money from the Defendant in the Mortgage Deed No.136 / 29 / ckd / 1997 with the Plaintiff's assets as collateral.

The plaintiff's increased debt from Rp.639,000,000 to \pm 25 billion rupiah was considered by the plaintiff as a loss since the agreement changed. Despite the plaintiff's material loss, the Serang District Court and Banten High Court did not grant it and even the plaintiff was declared as a bad one. The Supreme Court agreed with judex facti (verdicts of the District Court and the High Court) and stated that the Amendment Agreement did not nullify the mortgage of object of the case. Therefore, the plaintiff was still considered to have debts to the Defendant.

Undue influence is interesting for scientific studies to be able to provide input to the legislators in order to perfect the defect requirements of the will set out in Article 1321 of the Civil Code, because it is contrary to the principle of freedom of contract, the principle of good faith, as well as the principles of propriety and habit. It is also expected that there will be a uniform legal consideration for Indonesian court judges in order to achieve legal justice and legal certainty.

\subsection{Conflicts of Undue Influence}

Undue influence is contrary to the principle of freedom of contract, the principle of good faith, as well as the principle of propriety and habit. Freedom of contract requires that each party's bargaining position is balanced from one to another. It can provide the parties freedom to agree according to their interests.

Good faith is formed when legal relations are carried out in agreements, and when carrying out rights and obligations arising from legal relations. Good faith forms an inner attitude to be responsible, as a counterweight to the principle of legal certainty. Free will does not mean absolute but it must also be in accordance with the principles of propriety, habits, and decency.

The principle of good faith in Article 1338 paragraph (3) of the Civil Code functions as a counterweight to the principle of legal certainty in Article 1338 paragraph (1) of the Civil Code. The combination of the principle of good faith and the principle of legal certainty can protect the weak party so that in turn the position of the parties in an agreement must be proportional. 
Undue influence puts pressure on the weak party by getting around the situation / position of the economy being squeezed as an excuse to force the weak party to have no other choice. In this condition the weak party no longer has free will and the more dominant party seems to have bad faith.

\section{Conclusion}

Cancellation of agreement based on the doctrine of undue influence in the Indonesian court verdicts has been widely applied. From a number of the court verdicts granting the cancellation of the agreement using the doctrine or teachings of the undue influence, it can be concluded that the standard of the cancellation of the agreement based on the undue influence doctrine is still following the teachings of the undue influence developed by Van Dunne who mentioned that undue influence occurs due to two main factors: the economic excellence factor and the psychiatric excellence factor. Several elements used to see the event are (1) the existence of a special circumstance, (2) a real thing, (3) abuse of circumstance, and (4) causal relationship.

Undue influence although is not yet regulated in the Civil Code, it is contrary to the principle of freedom of contract, the principle of good faith, and the principle of propriety and habit. Therefore, it is seen as an urgent need to make it as a legal norm in the Civil Code. The result of this study is expected to be able to provide inputs to the legislators in order to improve the conditions of will defect stipulated in Article 1321 of the Civil Code. Thus, Indonesian judges are also expected to have uniformity of legal considerations in order to achieve legal justice and legal certainty.

\section{References}

Agus Yudha Hernoko. (2011). Hukum Perjanjian, Asas Proporsionalitas Dalam Kontrak Komersil, (Jakarta: Kencana), hal. 112.

Ahmadi Miru. (2010). Hukum Kontrak Perancangan Kontrak, (Jakarta: Rajawali Pers), hal. 165

A. Rahim. (2014).“Penyalahgunaan Keadaan Dalam Hukum Perjanjian”, Jurnal Jurisprudence, Volume 1 Nomor 2 Desember, hal. 86

AZ. Nasution. (2001). Hukum Perlindungan Konsumen, (Jakarta: Diadit Media), hal. 94

Endro Martono. (2015). "Penyalahgunaan Keadaan Sebagai Dasar Pembatalan Perjanjian", Jurnal Yustisia Merdeka, Vol.1, No.2, September, hal. 10.

Fatmah Paparang. (2016). "Misbruik Van Omstandigheden Dalam Perkembangan Hukum Kontrak", Jurnal Hukum Unsrat, Vol.22, No.6, Juli, hal. 50.

Gunawan Widjaja. (2005). Tanggung Jawab Direksi Atas Kepailitan Perseroan, (Jakarta: RajaGrafindo Persada), hal. 23.

H.P. Panggabean. (2010). Penyalahgunaan Keadaan (Misbruik Van Omstandigheden) Sebagai Alasan (Baru) Untuk Pembatalan Perjanjian, (Yogyakarta: Liberty), hal. 75.

J.M. van Dunne \& Gr. Van der Burght. (1987). Diterjemahkan oleh Sudikno Mertokusumo, "Penyalahgunaan Keadaan", Kursus Hukum Perikatan-Bagian III, Dewan Kerjasama Ilmu Hukum Belanda Dengan Indonesia, Proyek Hukum Perdata, Yogyakarta, hal. 11.

Ketut Sendra. (2004). Konsep dan Penerapan Asuransi Jiwa Unit Link, Proteksi Sekaligus Investasi, Buku Penentuan Agen dan Konsultan Keuangan Untuk Sukses Meraih Lisensi, (Yogyakarta: Bayu Indra Grafika), hal. 89. 
Latifa Mustafida. (2017). "Penerapan Doktrin Misbruik Van Omstandigheiden Terhadap Pembatalan Akta Notaris Berdasarkan Putusan Pengadilan", Jurnal Lex Renaissance, Vol.2, No. 1, Januari, hal. 65.

Mariam Darus Badrulzaman. (2001). Kompilasi Hukum Perikatan, (Bandung: Citra Aditya Bakti), hal. 20.

Muhammad Arifin. (2011). "Penyalahgunaan Keadaan Sebagai Faktor Pembatas Kebebasan Berkontrak", Jurnal Ilmu Hukum, Vol. 14, No. 2, September, hal. 288.

Muhammad Syaifuddin. (2012). Hukum Kontrak, Memahami Kontrak Dalam Perspektif Filsafat, Teori, Dogmatik, dan Praktik Hukum (seri Pengayaan Hukum Perikatan), (Bandung: Mandar Maju), hal. 216.

Megarita. (2015). "Legal Concepts the Freedom of Contract in Bank Credit Agreement", Journal of Business \& Economic Policy, Vol. 2, No. 3, September, hal. 52.

Munir Fuady. (2015).Hukum Kontrak, (Bandung: Citra Adtya Bakti), hal. 46.

Ridwan Khairandy. (2014). Hukum Kontrak Indonesia: Dalam Perspektif Perbandingan, (Yogyakarta: FH UII Press), hal. 75.

R. Subekti. (1979). Hukum Perjanjian, (Bandung: Intermasa), hal. 17.

R. Setiawan. (1999). Pokok-pokok Hukum Perikatan, (Jakarta: Putra Abadi), hal. 38.

Sukirman. (2009). "Pembatasan Kebebasan Berkontak", Jurnal Yustitia, Vol.9, No.1, Nopember, hal. 8.

Theresia Ngutra. (2016 ). "Hukum Dan Sumber-Sumber Hukum", Jurnal Supremasi, Vo.XI, No.2, Oktober, hal. 193, dan hal. 208.

Yahman. (2011). Karakteristik Wanprestasi \& Tindak Pidana Penipuan Yang Lahir Dari hubungan Kontraktual, (Jakarta: Prestasi Pustakaraya), hal. 31. 